\title{
MOBILE LEARNING ACCORDING TO STUDENTS OF COMPUTER ENGINEERING AND COMPUTER EDUCATION: A COMPARISON OF ATTITUDES
}

\author{
Dr. Deniz Mertkan GEZGIN \\ Department of Computer Education and Instructional Technology \\ Trakya University, Edirne, Turkey \\ Dr. Muge ADNAN \\ Informatics Department / Distance Education Center Education \\ Mugla Sitki Kocman University, Mugla, Turkey \\ Dr. Meltem ACAR GUVENDIR \\ Department of Measurement and Evaluation in Education \\ Trakya University, Edirne, Turkey
}

\section{ABSTRACT}

Mobile learning has started to perform an increasingly significant role in improving learning outcomes in education. Successful and efficient implementation of $\mathbf{m}$-learning in higher education, as with all educational levels, depends on users' acceptance of this technology. This study focuses on investigating the attitudes of undergraduate students of Computer Engineering (CENG) and Computer Education and Instructional Technology (CEIT) departments in a Turkish public university towards m-learning from three perspectives; gender, area of study, and mobile device ownership. Using a correlational survey method, a Mobile Learning Attitude Scale (MLAS) was administered to 531 students, analysis of which revealed a positive attitude to $\mathrm{m}$-learning in general. A further investigation of the aforementioned three variables showed a more positive attitude for female students in terms of usability, for CEIT students in terms of advantages, usability and independence, and for those owning a mobile device in terms of usability. An important implication from the findings, among others, is supplementing Computer Engineering curriculum with elective courses on the fundamentals of mobile learning, and/or the design and development of m-learning software, so as to create, in the long run, more specialized and complementary teams comprised of trained CENG and CEIT graduates in m-learning sector.

Keywords: M-learning, education, attitude, mobile programming, mobile technologies.

\section{INTRODUCTION}

Advancements in information and communication technologies present great opportunities for the delivery of education. This is no exception for mobile technologies, which broadens the scope of learning beyond the classroom walls through flexible, anywhere-anytime digital resources. This flexibility of mobile technologies has brought the concept of mobile learning (or m-learning) to the fore (Sharples, 2000), which allows us to access and use learning content through mobile technologies independent of time, space and location. It is not unusual to see people using smartphones or tablet PCs to access the Internet, play games, listen to music or watch videos at any moment; today, this is also true for teachinglearning environments, either formally or informally. Mobile devices are particularly preferred for data storage or access to information through course materials, e-books, etc. (Sarrab, 2015). Due to its prospects in education, scholars in the field of learning, instructional design and technology are still working on developing theoretical conceptions of the potential of mobile devices to inspire new forms of learning and engagement. This 
increased interest in mobile devices and their use for instructional purposes can be credited to a number of factors, as Milosevic, Zivkovic, Manasijevic, and Nikolic (2015) listed, including the expansion of wireless networks, ever-improving power and capacity of next generation mobile phones, and infiltration of mobile phones into our daily lives as communication devices. These social and technical attributes come to the fore with studies underlining that mobile learning typically occurs outside the classroom, particularly in higher education (e.g. Chen \& Denoyelles, 2013). Mobile devices and applications running on these devices also allow to users search, discover and even produce content, in addition to consuming it. Hence, these technologies are changing the way we access information, use information, and transforming how we learn. Their role in the academic lives of students become increasingly important, and thorough examination of attitudes and perceptions of stakeholders (instructors, learners and institutions) reveals meaningful suggestions for the design, development, and management of integration of mobile technologies into teaching and learning environments as a powerful means as to achieving the desired result.

\section{THEORETICAL BACKGROUND OF M-LEARNING}

Quinn (2000) defined mobile learning in 2000 as "the intersection of mobile computing and e-learning: accessible resources wherever you are, strong search capabilities, rich interaction, powerful support for effective learning, and performance-based assessment. ELearning independent of location in time or space."

According to Keegan (2005) as well, the focus of the definition of mobile learning should be on mobility:

Mobile learning should be restricted to learning on devices which a lady can carry in her handbag or a gentleman can carry in his pocket. I therefore define mobile learning as 'the provision of education and training on PDAs/palmtops/handhelds, smartphones and mobile phones. One of the characteristics of mobile learning is that it uses devices:

$>\quad$ Which citizens are used to carrying everywhere with them,

$>$ Which they regard as friendly and personal devices,

$>\quad$ Which are cheap and easy to use,

$>\quad$ Which they use constantly in all walks of life and in a variety of different settings, except education. (p. 3)

Ally (2004) defined mobile learning as "the delivery of electronic learning materials on mobile computing devices to allow access from anywhere and at any time" (p. 5). Other definitions also emphasized the mobility and nomadicity of learners ( $0^{\prime}$ Malley et al., 2003; Shon, 2008). Being continuously on the move, Ally (2007) predicted today's learners demanding course content delivered on mobile devices to be accessed at anytime from anywhere. Hence, mobile learning is characterized as a strong element of education for facilitating the learning experiences, and has an increasingly remarkable role in higher education. By using mobile technology, students can easily and quickly access and use learning resources anytime, anywhere.

Easy and quick access independent of time and space credits to two important benefits to mobile learning in the eyes of students: practicality (e.g. where students can study whenever or from wherever they prefer, or making course materials accessible for those with particular disabilities) and portability (e.g. ability to carry mobile devices lighter than books or allowing students to take notes, type text or record sound irrespective of location). Researchers also underline interaction (where students have continuous interaction with instructors), cooperation (enabling cooperation among students even in remote locations), engagement (engaging for students coming from a generation where mobile devices are part of everyday life), speed (relatively quick development and availability of learning materials), retention of knowledge (mobile learning as a powerful learning tool providing quick reminders and additions to existing materials), reduced costs 
(enabling easier data management through reduced printing needs) (MacCallum \&Kinshuk, 2008; Toteja \& Kumar, 2012). Additionally, many studies suggest that m-learning positively contributes to student engagement (Huizenga, Admiraal, Akkerman, \& Dam, 2009; Karsenti \& Fievez, 2013;Gupta, \& Manjrekar, 2012; Rossing, Miller, Cecil, \& Stamper, 2012), learning achievement (Al-Emran, Elsherif, \& Shaalan, 2016;Hwang, Wu, \& Ke, 2011; Wu, Hwang, Su, \& Huang, 2012; Zaldívar, Tripp, Aguilar, Tovar, \& Anguiano, 2015; Pfeiffer,Gemballa, Jarodzka, Scheiter, \& Gerjets, 2009; Rossing et al., 2012), motivation (Schwabe \& Goth, 2005; Kinash, Brand, \& Mathew, 2012; Milosevic et al., 2015), interest (Tan \& Liu, 2004; Uzunboylu, Cavus, \& Ercag,2009; Suki \& Suki, 2011a), positive attitude (Baya'a \& Daher, 2009;Hwang \& Chang, 2011; Jaradat, 2014; Kutluk \& Gulmez, 2014; Al-Fahad, 2009; Ozdamli \& Uzunboylu, 2015; Liaw \& Huang, 2015; Yang, 2012), and critical thinking skills (Cavus \& Uzunboylu, 2009). On the other hand, there are also certain challenges reported of using mobile technologies in education including problematic access to Internet particularly in remote areas in developing countries, physical and psychological problems caused by intensive use of mobile devices like nomophobia or panic disorders, poorly designed materials, lack of adoption by instructors, and a lack of awareness or negative attitude by students. Regarding the latter two challenges, Kukulska-Hulme (2007) states that successful development of mobile learning depends on human factors in the use of new mobile and wireless technologies. Therefore, it becomes significant to investigate the factors affecting the intention to use and attitude towards mobile learning by students at higher education institutions.

There are several studies in the literature about attitudes of higher education students towards mobile learning, which consider it as a significant factor to understand what makes end users accept or resist mobile learning. Some international studies reveal that university students generally have a positive attitude towards the use of mobile devices in education and mobile learning (Baya'a \& Daher, 2009; Hwang \& Chang, 2011; Al-Fahad, 2009; Ozdamli \& Uzunboylu, 2015; Liaw \& Huang, 2015; Yang, 2012). Studies conducted in Turkey also indicate a positive attitude towards mobile learning (e.g. Kukul, Gokcearslan, \& Karademir, 2015). Another recent study by Elcicek and Bahceci (2015) reveal a positive attitude towards mobile learning by students enrolled on a two-year associate degree program. Sarac's study (2014) also concludes highly positive attitudes by candidate instructional technologists towards mobile learning as a new learning platform. There are few studies in the national literature conducted with participation from students enrolled in computer science departments. One reason for this might be an impression that their attitude towards mobile learning will naturally be positive. Yet, being potential designers and developers of mobile learning applications and materials, it is vital to investigate perceptions and attitudes of university students from such departments in light of their future roles aimed at the efficient design, development, usage and expansion of mobile technologies.

This study investigates attitudes towards mobile learning by students of Computer Education and Instructional Technologies (CEIT) and Computer Engineering (CENG) departments. Students' attitudes are also examined on the basis of gender, department and mobile device ownership variables. It is considered important to investigate and compare attitudes of CEIT and CENG students towards mobile learning since one professional path for the graduates of these two computer science-based departments is likely to be related to the design, development and implementation of mobile learning software and associated projects. Hence, in order for contributing to effective and sound mobile learning activities, it is vital to reveal attitudes of these students covering their interests, beliefs and behaviors towards mobile technologies and their use for educational purposes.

\section{PURPOSE OF THE STUDY}

The purpose of this study is to investigate the attitudes of Turkish university students from CENG and CEIT departments towards mobile learning. To this aim, answers to the following research questions have been sought: 
$>$ What are the attitudes of students at CENG and CEIT departments towards $\mathrm{m}$ learning?

$>$ Is there a significant difference between the attitudes of students at CENG and CEIT departments towards m-learning in terms of gender?

$>$ Is there a significant difference between the attitudes of students at CENG and CEIT departments towards m-learning in terms of department?

$>$ Is there a significant difference between the attitudes of students at CENG and CEIT departments towards m-learning in terms of mobile device ownership?

\section{METHODOLOGY}

This study is designed as a correlational survey research, where there are a minimum of two variables for comparative purposes. Groups are formed on the basis on one of the variables, and analysis is conducted to see whether or not there is a difference based on the other variable (Karasar, 2012). It is not possible to mention a causal relationship in these studies, since conditions are unidentical (Buyukozturk, Cakmak, Akgun, Karadeniz, \& Demirel, 2008; Karasar, 2012). According to Creswell (2012), investigators use the correlational statistics to describe and measure the degree or association between two or more variables or sets of score in correlational research. These research have been elaborated into more complex relationships among variables (Creswell, 2014). Also Fraenkel \& Wallen (2000) said, "Correlational research is an example of what is sometimes called associational research. In associational research, the relationships among two or more variables are studied without any attempt to influence them" (p. 359).

\section{Participants of the Study}

Participants of the study are students enrolled in the Computer Engineering Department (CENG) and the Department of Computer Education and Instructional Technology (CEIT) of Trakya University, Turkey. There are 745 students enrolled, of which 531 participated voluntarily in the study. Demographic information of the participants is given in Table1.

Table 1. Demographic statistics of students

\begin{tabular}{llll}
\hline & & N & $\%$ \\
\hline Gender & Male & 354 & 66.7 \\
Femartment & CENG & 177 & 33.3 \\
& CEIT & 365 & 68.7 \\
Year in program & 1st grade & 166 & 31.3 \\
& 2nd grade & 141 & 26.6 \\
& 3rd grade & 153 & 28.8 \\
& 4th grade & 154 & 29.0 \\
& Yes & 473 & 89.1 \\
\hline $\begin{array}{l}\text { Mobile device } \\
\text { Ownership }\end{array}$ & No & 58 & 10.9 \\
\hline
\end{tabular}

\section{Data Collection}

Data was collected through a Likert-type M-Learning (Mobile Learning) Attitude Scale, as developed by Celik (2013), in order to measure attitudes of college students towards $\mathbf{m}$ learning. Results from the exploratory factor analysis indicate four factors with an eigenvalue over 1.00 , which explains $51.12 \%$ of the total variance: advantages of $\mathrm{m}$ learning (first factor), limitations of $\mathbf{m}$-learning (second factor), practicality of $\mathbf{m}$-learning 
(third factor), and independence in m-learning (fourth factor). Internal consistency reliability of the study's data was measured using Cronbach alpha coefficient, which indicated a 0.80 value for the first factor, 0.77 for the second factor, 0.78 for the third factor, and $\mathbf{0 . 7 7}$ for the fourth factor. The analysis was replicated for this current study, and resulted in $\mathbf{0 . 7 8}$ for the first factor, $\mathbf{0 . 6 4}$ for the second factor, $\mathbf{0 . 7 0}$ for the third factor, and $\mathbf{0 . 7 4}$ for the fourth factor.

\section{Data Analysis}

Multivariate analysis of variance (MANOVA), a parametric method, was used to determine whether or not students' attitudes towards m-learning vary as of gender, department, and ownership of a mobile device.

Firstly, the extreme values in the data set have been determined in order to meet the assumption of normality from MANOVA's assumptions. For this assumption, the item scores have been converted to standard $\mathrm{z}$ scores and points other than -3 and +3 were determined (Tabachnick \& Fidel, 2007). A total of 25 rows were removed from the data set. Then, univariate normality distribution of data for each factor upon testing hypotheses for MANOVA was calculated and shown on Table 2.

Table 2. Skewness and kurtosis values for factor scores for each variable

\begin{tabular}{|c|c|c|c|c|c|}
\hline & & & $\mathbf{N}$ & Skewness & Kurtosis \\
\hline \multirow[t]{6}{*}{ Advantages } & Gender & Male & 354 & -.23 & -.15 \\
\hline & & Female & 177 & -.49 & .69 \\
\hline & Department & CENG & 365 & -.18 & -.05 \\
\hline & & CEIT & 166 & -.29 & -.29 \\
\hline & Mobile Device Ownership & Yes & 473 & -.33 & .09 \\
\hline & & No & 58 & -.20 & .37 \\
\hline \multirow[t]{6}{*}{ Limitations } & Gender & Male & 354 & .02 & .05 \\
\hline & & Female & 177 & .18 & .04 \\
\hline & Department & CENG & 365 & .09 & -.05 \\
\hline & & CEIT & 166 & .04 & .33 \\
\hline & Mobile Device Ownership & Yes & 473 & .03 & .06 \\
\hline & & No & 58 & .48 & .03 \\
\hline \multirow[t]{6}{*}{ Practicality } & Gender & Male & 354 & -.40 & -.16 \\
\hline & & Female & 177 & -.63 & .84 \\
\hline & Department & CENG & 365 & -.54 & .32 \\
\hline & & CEIT & 166 & -.19 & -.12 \\
\hline & Mobile Device Ownership & Yes & 473 & -.51 & .37 \\
\hline & & No & 58 & -.43 & .41 \\
\hline \multirow[t]{6}{*}{ Independence } & Gender & Male & 354 & -.47 & -.13 \\
\hline & & Female & 177 & -.65 & .32 \\
\hline & Department & CENG & 365 & -.39 & -.33 \\
\hline & & CEIT & 166 & -.65 & .99 \\
\hline & Mobile Device Ownership & Yes & 473 & -.54 & .04 \\
\hline & & No & 58 & -.50 & .48 \\
\hline
\end{tabular}

Table 2 gives skewness and kurtosis values to see normality distribution for each variable (gender, department, mobile device ownership) under each factor. As known, skewness and kurtosis values are zero under standard normal distribution. Having values ranging between +1 and -1 indicates that distribution does not deviate extremely from normal distribution (Mertler \& Vannatta, 2005). Table 2 shows that skewness and kurtosis coefficients for factor scores vary between +1 and -1 , which indicates no deviation from the normal distribution. 
Also, the Bartlett Sphericity Test showing the assumption of multivariate normality was made and found significant (313.431; $\mathrm{p}<.01)$. According to this result, the data meet the multivariate normality assumption.

One of the assumptions that must be provided for MANOVA is the lack of a multiple linear relationship between dependent variables. In order to use MANOVA, dependent variables must be related to each other theoretically (Leech, Barret \& Morgan, 2005). On the other hand, the fact that the relationship between dependent variables is too high (Correlation coefficients over $\mathbf{8 0}$ or .90) causes problems in MANOVA (Pallant, 2005). Correlation values were calculated in this study as radvantages\&Limitations $=-.123$; $\mathrm{r}_{\text {Advantages\&practicality }=.298 \text {; }}$ $r_{\text {Advantages\&independence }=.489 ;}$ r $\quad$ Limitations\&practicality $=-.188 ; \quad$ rLimitations\&independence $=-.229$; rpracticality\&independence=.471. Accordingly, there are no multiple linear relationships among dependent variables.

Another assumption for the use of MANOVA is homogeneity of variance covariance matrices. The "Box's M" test is used for this. The statistical significance of the Box's M test indicates that the assumption of homogeneity of variance-covariance matrices is provided and the statistical insignificance of the Box's $M$ test suggests that this assumption is violated. The significance of the Box's $M$ test is significantly influenced by the number of participants in the study and the Box's $M$ test can be made much more significant when the number of participants is high. Therefore, the significance level for this test is suggested to be taken as .025, .01 (Mertler \& Vannatta, 2010) or .001 (Pallant, 2005). In this study, the significance level for the Box's $M$ test was taken as .01. In the study, the significance value for the Box's $M$ test calculated for the dependent variable data set consisting of independent variables shows that the assumption of homogeneity of the variance covariance matrices for the independent variables is met (gender [Box's $M=4.801, p>.01$, department [Box's $M=66.021, p>01]$, and Mobile Device Ownership [Box's $M=16.471$, p>.01].

\section{FINDINGS}

Multivariate analysis of variance (MANOVA) was conducted in order to determine whether or not each factor score varies according to gender, department, and ownership of mobile device.

Table 3. MANOVA results for average scores as of variables

\begin{tabular}{lcccccc}
\hline & Wilks'Lambda & $\mathbf{F}$ & Hypothesis sd & Error sd & $\mathbf{p}$ & $\eta^{2}$ \\
\hline Gender & .98 & 2.88 & 4.00 & 526.00 & .02 & .02 \\
Department & .96 & 5.68 & 4.00 & 526.00 & .00 & .04 \\
Mobile Device Ownership & .98 & 2.99 & 4.00 & 526.00 & .02 & .02 \\
\hline
\end{tabular}

MANOVA results indicate a significant difference for each factor according to students' gender, department enrolled, and ownership of a mobile device [Wilks lambda (gender) $=.98$, $F_{(4 ; 526)}=2.88, p<.05$; Wilks lambda (department) $=.96, F_{(4 ; 526)}=5.68, p<.01$; Wilks lambda (mobiledevice) $\left.=.98, F_{(4 ; 526)}=.98, p<.05\right]$. This finding suggests that scores received from the scale change according to the gender, department, and mobile device ownership. Analysis has also covered the effect size (eta-squared) to show the extent of the independent variable's effect on the dependent variable. The effect size is interpreted as 'small' for .01 $\leq \eta^{2}<.06$, 'medium' for $0.06 \leq \eta^{2}<.14$, and 'large' for $\eta^{2} \geq .14$ (Cohen, 1988). Accordingly, it can be said that gender, department and ownership of mobile device have a small effect on the factor $\left(\eta^{2}\right.$ gender $=.02 ; \eta^{2}$ department $=.04 ; \eta^{2}$ mobiledevice $\left.=.02\right)$. 
Table 4 gives mean and standard deviation values for the four factors of the scale, along with factor-based one-way ANOVA results for gender.

Table 4. Mean, standard deviation and ANOVA results as of gender

\begin{tabular}{|c|c|c|c|c|c|c|c|c|}
\hline Dependent Variable & Gender & $\mathbf{N}$ & $\bar{X}$ & SS & $\mathbf{F}$ & Sd & $\mathbf{p}$ & $\eta^{2}$ \\
\hline Advantages & $\begin{array}{c}\text { Male } \\
\text { Female }\end{array}$ & $\begin{array}{l}354 \\
177\end{array}$ & $\begin{array}{l}26.21 \\
26.09\end{array}$ & $\begin{array}{l}4.68 \\
4.54\end{array}$ & .08 & $1-529$ & .78 & .00 \\
\hline Limitations & $\begin{array}{l}\text { Male } \\
\text { Female }\end{array}$ & $\begin{array}{l}354 \\
177 \\
\end{array}$ & $\begin{array}{l}16.60 \\
16.35 \\
\end{array}$ & $\begin{array}{l}3.65 \\
3.38 \\
\end{array}$ & .59 & $1-529$ & .44 & .00 \\
\hline Practicality & $\begin{array}{c}\text { Male } \\
\text { Female }\end{array}$ & $\begin{array}{l}354 \\
177 \\
\end{array}$ & $\begin{array}{l}19.20 \\
19.87 \\
\end{array}$ & \begin{tabular}{|l|}
3.38 \\
2.93 \\
\end{tabular} & 4.91 & $1-529$ & .03 & .01 \\
\hline Independence & $\begin{array}{c}\text { Male } \\
\text { Female }\end{array}$ & $\begin{array}{l}354 \\
177\end{array}$ & $\begin{array}{l}15.32 \\
15.33\end{array}$ & $\begin{array}{l}2.97 \\
2.87\end{array}$ & .01 & $1-529$ & .96 & .00 \\
\hline
\end{tabular}

As seen in Table 4, average scores for advantages, limitations and independence of $\mathrm{m}$ learning do not indicate a significant difference as of students' gender [ $F_{\text {advantage }(1 ; 529)}=.08$, $\mathrm{p}>.05$; Flimitation(1;529) $=.59, \mathrm{p}>.05$; Findependence $(1 ; 529)=.01, \mathrm{p}>.05]$, whereas there is significant difference among the average scores for practicality[ $\left.F_{\text {practicality }(1 ; 529)}=4.91, p<.05\right]$. Accordingly, female students' average scores for practicality of $\mathbf{m}$-learning factor are higher than that of male students, which might indicate that female students have a more positive attitude towards practicality of m-learning compared to male students. Besides, a review of the effect size shows that gender may have a small effect on the average scores for the factor on practicality of $\mathbf{m}$-learning $\left(n^{2}\right.$ practicality $\left.=.01\right)$.

Table 5 gives mean and standard deviation values for the four factors of the scale, along with factor-based one-way ANOVA results for department enrolled.

Table 5. Mean, standard deviation and ANOVA results as of department

\begin{tabular}{|c|c|c|c|c|c|c|c|c|}
\hline $\begin{array}{l}\text { Dependent } \\
\text { Variable }\end{array}$ & Department & $\mathbf{N}$ & $\bar{X}$ & SS & $\mathbf{F}$ & Sd & $\mathbf{p}$ & $n^{2}$ \\
\hline Advantages & $\begin{array}{l}\text { CENG } \\
\text { CEIT }\end{array}$ & $\begin{array}{l}365 \\
166\end{array}$ & $\begin{array}{l}25.55 \\
27.54\end{array}$ & $\begin{array}{l}4.86 \\
3.76\end{array}$ & 21.79 & $1-529$ & .00 & .04 \\
\hline Limitations & CENG & 365 & 16.43 & & .80 & $1-529$ & .37 & .00 \\
\hline & CEIT & 166 & 16.72 & 3.51 & & & & \\
\hline Practicality & CENG & 365 & 19.21 & 3.36 & 5.04 & $1-529$ & .03 & .01 \\
\hline & CEIT & 166 & 19.89 & 2.95 & & & & \\
\hline Independence & $\begin{array}{l}\text { CENG } \\
\text { CEIT }\end{array}$ & $\begin{array}{l}365 \\
166\end{array}$ & $\begin{array}{l}15.00 \\
16.03\end{array}$ & $\begin{array}{l}3.12 \\
2.35\end{array}$ & 14.28 & $1-529$ & .00 & .03 \\
\hline
\end{tabular}

As seen in Table 5, average scores for limitation do not indicate a significant difference as of students' department [Flimitation $(1 ; 529)=0.80, p>.05$ ], whereas there is significant difference among average scores for advantages, practicality and independence of $\mathbf{m}$ learning $\left[F_{\text {advantage }}(1 ; 529)=21.79, p<.01 ; F_{\text {practicality }}(1 ; 529)=5.04, p<.05 ;\right.$ Findependence $(1 ; 529)$ $=14.28, p<.01]$. Accordingly, average scores of CEIT students for advantages, practicality and independence of m-learning are higher than that of CENG students, which might indicate that CEIT students have a more positive attitude towards advantages, practicality and independence of $\mathbf{m}$-learning compared to CENG students. Besides, a review of the effect size shows that department variable may have a small effect on the average scores for the factors on advantages, practicality, and independence of $\mathrm{m}$-learning $\left(\eta^{2}\right.$ advantage $=.04$; $\eta^{2}$ practicality $=.01 ; \eta^{2}$ independence $=.03$ ).

Table 6 gives mean and standard deviation values for four factors of the scale, along with factor-based one-way ANOVA results for mobile device ownership. 
Table 6. Mean, standard deviation and ANOVA results as of mobile device ownership

\begin{tabular}{|c|c|c|c|c|c|c|c|c|}
\hline $\begin{array}{c}\text { Dependent } \\
\text { Variable }\end{array}$ & $\begin{array}{l}\text { Mobile Device } \\
\text { Ownership }\end{array}$ & $\mathbf{N}$ & $\bar{X}$ & SS & $\mathbf{F}$ & Sd & $\mathbf{p}$ & $\eta^{2}$ \\
\hline Advantages & $\begin{array}{l}\text { Yes } \\
\text { No }\end{array}$ & $\begin{array}{c}473 \\
58\end{array}$ & $\begin{array}{l}26.21 \\
25.84\end{array}$ & $\begin{array}{l}4.67 \\
4.33\end{array}$ & .33 & $1-529$ & .57 & .00 \\
\hline Limitations & $\begin{array}{l}\text { Yes } \\
\text { No }\end{array}$ & $\begin{array}{c}473 \\
58 \\
\end{array}$ & $\begin{array}{l}16.53 \\
16.43 \\
\end{array}$ & $\begin{array}{l}3.59 \\
3.37 \\
\end{array}$ & .04 & $1-529$ & .83 & .00 \\
\hline Practicality & $\begin{array}{l}\text { Yes } \\
\text { No }\end{array}$ & $\begin{array}{c}473 \\
58\end{array}$ & $\begin{array}{l}19.57 \\
18.24\end{array}$ & $\begin{array}{l}3.23 \\
3.17\end{array}$ & 8.82 & $1-529$ & .00 & .02 \\
\hline Independence & $\begin{array}{l}\text { Yes } \\
\text { No }\end{array}$ & $\begin{array}{c}473 \\
58\end{array}$ & $\begin{array}{l}15.36 \\
15.03\end{array}$ & $\begin{array}{l}2.97 \\
2.65\end{array}$ & .66 & $1-529$ & .42 & .00 \\
\hline
\end{tabular}

According to Table 6, average scores for advantages, limitations, and independence of $\mathrm{m}$ learning do not indicate a significant difference as of mobile device ownership status $\left[F_{\text {advantage }(1 ; 529)}=.33, p>.05 ; F_{\text {limitation }(1 ; 529)}=.04, p>.05 ; F_{\text {independence(1;529) }}=.66, p>.05\right]$, whereas there is significant difference among average scores for practicality of $\mathbf{m}$-learning

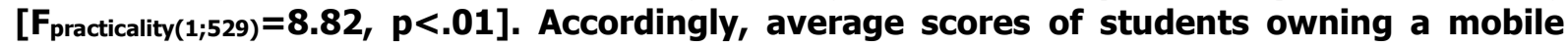
device for practicality of $\mathrm{m}$-learning are higher than that of those with no mobile device, which might indicate that students with mobile devices have a more positive attitude towards practicality of m-learning compared to those with no mobile devices. Besides, a review of the effect size shows that mobile device variable may have a small effect on the average scores for the factor on practicality of $\mathrm{m}$-learning $\left(n^{2}\right.$ practicality $\left.=.02\right)$.

\section{DISCUSSION AND CONCLUSION}

This current study investigated attitudes towards mobile learning by students of CEIT and CENG departments. The findings from the study indicate a positive attitude towards mobile learning in general. Students' attitudes were also examined on the basis of gender, department and mobile device ownership variables, findings from which were revealed in the following paragraphs.

Findings from the study indicate no significant difference, in terms of gender, among the average scores for advantages, limitations and independence of $\mathbf{m}$-learning. Nonetheless, female students have a more positive attitude towards the practicality factor of $\mathbf{m}$-learning compared to male students. It is possible to say that female and male students have different attitudes towards m-learning (Liaw \& Huang, 2015). Parallel to this study's findings, several studies also indicate that female students exhibit a more positive attitude compared to male students in terms of practicality of m-learning (Taleb \&Sohrabi,2012; Khaddage \& Knezek, 2013; Alwraikat \& Al Tokhaim,2014). Even so, there are other studies indicating that both female and male students with higher levels of attitudes towards $\mathbf{m}$ learning, yet there is no significant difference in terms of gender (Liaw \& Huang, 2015; Kukul et al., 2015; Wang, Wu, \&Wang, 2009; Yang, 2012; Cavus, 2011; Albert \& Johnson, 2011; Gonzalez-Gomez, Guardiola, Rodríguez, \& Alonso, 2012). Some studies explain this difference on the basis that women are more attracted to the practicality of technology (Jacob \& Issac, 2014), and some consider perceived self-regulation of female students as a significant predictor for perceived ease of use and perceived usefulness (Liaw \& Huang, 2015).

Findings point to CEIT students having a more positive attitude in terms of advantages, practicality and independence of m-learning compared to CENG students. Although both departments are technology-based, the curriculum of CEIT departments covers more courses about $\mathrm{m}$-learning by nature of the subject area. Computer engineering departments, on the other hand, more focus on 'technical' courses such as computer programming, which most students may think 'inappropriate' for mobile learning. Another reason may be lack or insufficient knowledge of mobile learning (Milosevic et al., 2015). The dissertation of Yilmaz (2011) concludes that participants who have not been exposed to $\mathbf{m}$-learning have a lower level of awareness of $\mathbf{m}$-learning, particularly in terms of its 
application. A study by Ozdamli, Soykan, and Yildiz (2013) conducted in Turkey with CEIT students also concludes that CEIT students who have attended e-learning activities and who use Internet regularly every day have a positive opinion about mobile learning, and wish to use mobile learning applications in their courses.

Findings from the current study indicate a higher average score on the practicality of $\mathbf{m}$ learning for students owning a mobile device compared to others. Hence, students having a mobile device exhibit a more positive attitude towards practicality of $\mathbf{m}$-learning. It may be said that mobile device ownership leads to a more positive attitude for students towards m-learning particularly in terms of ease-of-use and usefulness (Al-Emran et al., 2016; Cheon, Lee, Crooks, \& Song, 2012; Suki \& Suki, 2011b). There are conflicting studies concluding that mobile device ownership does not affect attitudes towards mobile learning (Kukul et al., 2015).

A successful and efficient $m$-learning practice heavily depends on organising and combining m-learning elements in a sound and vigorous manner (Ozdamli \& Cavus, 2011). It is imperative to apply fundamental m-learning strategies and principles in designing and developing mobile versions of course content. A simple, healthy user interface may help students gain more understanding of the topics covered (Alshalabi \& Elleithy, 2012). Computer engineers actively participate in the design and development of $\mathbf{m}$-learning applications, particularly in terms of infrastructure and programming. Hence, it would be beneficial to strengthen the training program in computer engineering departments with elective courses on mobile learning, or improving the course content so as to include design and development of mobile applications, and also to provide students with mobile learning opportunities for their own courses. Thus, it would be possible to familiarize them with active mobile learning practices, improve their attitudes towards mobile learning, and contribute to their learning through well-designed, effective mobile learning applications (Sung \& Mayer, 2013). A positive attitude towards mobile learning by computer engineers is important in terms of producing high-quality, effective and user-friendly materials, since they may actively take part in the design and development of mobile learning applications in their professional lives. Furthermore, inter-departmental projects between CENG and CEIT departments will enable students to have hands-on experience as future crucial parties of the mobile learning sector that will contribute to the development of high quality mobile learning materials transferring its affordances at utmost level possible.

Instructors' effective selection and use of mobile devices and appropriate mobile learning software in teaching-learning environments in a healthy and sound manner will improve learners' awareness and attitude towards mobile learning. This is particularly important considering the fact that it is not sufficient just for instructional designers and instructors to have basic theoretical knowledge about mobile learning; instead, they need to know how to integrate mobile technologies in their courses in a more effective way within the framework of relevant pedagogies (Park, 2011). Cheon et al. (2012) underline the hardship in "shifting the pedagogical culture to a mobile format" and emphasize the essence of orchestrating all stakeholders (instructors, learners, content, and institutions) "in creating a new pathway to learning with mobile devices" (p. 1054). In this regard, it may be useful to investigate the issue from several perspectives, including technology acceptance. Detailed examination of attitudes and perceptions of instructors, learners and institutions would reveal meaningful suggestions for design, development, and management of integration of mobile technologies into teaching and learning environments in a powerful manner as to achieve a desired result. 


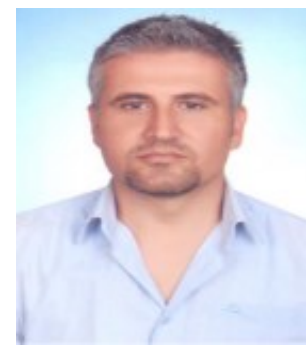

Dr. Deniz Mertkan GEZGIN was born in Kutahya, Turkey, in 1979. He graduated from Canakkale 18 Mart University, Faculty of Engineering, Department of Computer Engineering in 1999. He received his M.S and Ph.D. in Computer Engineering at Trakya University. He was a visiting scholar at METU in 2015. He has been working at Department of Computer Education and Instructional Technology, Faculty of Education in Trakya University as an Assistant Professor. His areas of interest are mobile learning, nomophobia, FoMo, technology acceptance, social networks, wireless networks, computer programming education and database design.

Assist. Prof. Dr. Deniz Mertkan GEZGIN

Trakya University Faculty of Education Department

of Computer Education and Instructional Technologies

Faculty of Education, Kosova Campus Aysekadin, Edirne, TURKEY

Phone: $\mathbf{+ 9 0 2 8 4 2 1 2 0 8 0 8}$

Email: mertkan@trakya.edu.tr

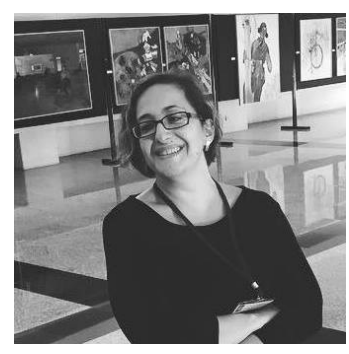

Dr. Muge ADNAN was born in Eskisehir, Turkey, in 1971. She received her BA and MA degrees from Hacettepe University (Turkey), Faculty of Letters, Department of English Language and Literature in 1992 and 1995 respectively. She received her Ph.D. in Computer Education and Instructional Technology from the Middle East Technical University in Ankara, Turkey. She worked for nationwide education projects financed by international institutions for 14 years. Since 2010, she has been working as an assistant professor at the Department of Computer Education and Instructional Technology, Faculty of Education, of Mugla Sitki Kocman University in addition to her administrative positions as the Head of Informatics Department and the Director of the Distance Education Center. Her areas of interest include teacher training, faculty development, technology integration, instructional technologies, elearning, online learning, social networks, mobile learning and nomophobia.

Assist. Prof. Dr. Muge ADNAN

Mugla Sitki Kocman University

Informatics Department / Distance Education Center

Kotekli Campus, Mugla, TURKEY

Phone: +902522111614

Email: muge@mu.edu.tr

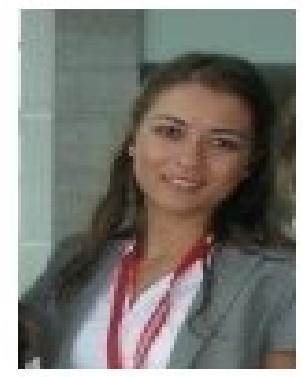

Dr. Meltem ACAR GUVENDIR was born in Kutahya, Turkey, in 1984. She received her B.A. from Ankara University, Faculty of Education, and Department of Elementary Education in 2006. In 2008, she received her M.S in Measurement and Evaluation in Education, Hacettepe University and she received her Ph.D. in Measurement and Evaluation in Education, Ankara University in 2013. She was a visiting scholar at University of California, Los Angeles (UCLA) between 2015 and 2016. She has been working at Department of Measurement and Evaluation in Education, Faculty of Education at Trakya University as an Assistant Professor. She has an interest in student achievement, multilevel models, scaling, and test development.

Assist. Prof. Dr. Meltem ACAR GUVENDIR

Trakya University Faculty of Education Department

of Measurement and Evaluation in Education

Faculty of Education, Kosova Campus Aysekadin, Edirne, TURKEY

Phone: $\mathbf{+ 9 0 2 8 4 2 1 2 0 8 0 8}$

Fax: $\mathbf{+ 9 0 2 8 4 2 1 4 6 2 7 9}$

Email: meltemacar@trakya.edu.tr 


\section{REFERENCES}

Albert, L. J., \& Johnson, C. S. (2011). Socioeconomic Status - and Gender-Based Differences in Students' Perceptions of E-Learning Systems. Decision Sciences Journal of Innovative Education, 9(3), 421-436.

Al-Emran, M., Elsherif, H. M., \& Shaalan, K. (2016). Investigating attitudes towards the use of mobile learning in higher education. Computers in Human Behavior, 56, 93-102.

Al-Fahad, F. N. (2009). Students' attitudes and perceptions towards the effectiveness of mobile learning in King Saud University, Saudi Arabia. The Turkish Online Journal of Educational Technology, 8(2), 111-119.

Ally, M. (2004). Using learning theories to design instruction for mobile learning devices. Proceedings of the Mobile Learning 2004 International Conference, Rome.

Ally, M. (2007). Guest Editorial-Mobile Learning. The International Review of Research in Open and Distributed Learning, 8(2)

Alshalabi, I., \& Elleithy, K. (2012). Effective M-learning design Strategies for computer science and Engineering courses. International Journal of Mobile Network Communications \& Telematics (IJMNCT), 2(1). Retrieved from http://arxiv.org/abs/1203.1897.

Alwraikat, M. A., \& Al Tokhaim, H. (2014). Exploring the Potential of Mobile Learning Use among Faculty Members. International Journal of Interactive Mobile Technologies (iJIM), 8(3), 4-10.

Baya'a, N. F., \& Daher, W. M. (2009). Learning Mathematics in an Authentic Mobile Environment: The Perceptions of Students. iJIM, 3(SI), 6-14.

Buyukozturk, S., Cakmak, E. K., Akgun, O. E., Karadeniz, S., \& Demirel, F. (2008). Bilimsel arastırma yontem/eri [Scientific Research Methods].Ankara, Turkey: Pegem Academy Publishing.

Cavus N. (2011). Investigating mobile devices and LMS integration in higher education: student perspectives. Procedia Computer Science, 3, 1469-1474.

Cavus, N., \& Uzunboylu, H. (2009). Improving critical thinking skills in mobile learning. Procedia-Social and Behavioral Sciences, 1(1), 434-438.

Chen, B., \& Denoyelles, A. (2013). Exploring Students' Mobile Learning Practices in Higher Education. Educause Review Online. Retrieved from http://www.educause.edu/ero/article/exploringstudents-mobile-learningpractices-higher-education.

Cheon, J., Lee, S., Crooks, S. M., \& Song, J. (2012). An investigation of mobile learning readiness in higher education based on the theory of planned behavior. Computers \& Education, 59(3), 1054-1064.

Creswell, J. W. (2012). Educational research: Planning, conducting, and evaluating quantitative and qualitative research (4th ed.). Boston, MA: Pearson Education, Inc

Creswell, J. W. (2014). Research design: Qualitative, quantitative, and mixed methods approaches. Thousand Oaks: Sage publications.

Cohen, J. (1988). Statistical power analysis for the behavioral sciences (2nd ed.). Hillsdale, NJ: Erlbaum.

Celik, U. A. (2013). M-Ogrenme Tutum Olcegi: Gecerlik ve Guvenirlik Analizleri [MLearning Attitude Scale: Validity and Reliability Analyses]. Journal of Research in Education and Teaching, 2(4), 172-185. 
Elcicek, M., \& Bahceci, F. (2015). The Research of the Vocational School Student's Attitudes towards Mobile Learning. The Journal of Education Faculty Sakarya University, 30, 17-33.

Fraenkel, J. R., \& Wallen, N. E. (2000). How to design \& evaluate research in education (4th Ed.). Boston: McGraw Hill.

Gonzalez-Gomez, F., Guardiola, J., Rodríguez, O. M., \& Alonso, M. A. M. (2012). Gender differences in e-learning satisfaction. Computers \& Education, 58, 283-290.

Gupta, M., \& Manjrekar, P. (2012). Using mobile learning to enhance quality in higher education. SIES Journal of Management, 8(1), 23-30.

Huizenga, J., Admiraal, W., Akkerman, S., \& Dam, G. T. (2009). Mobile game-based learning in secondary education: engagement, motivation and learning in a mobile city game. Journal of Computer Assisted Learning, 25(4), 332-344.

Hwang, G. J., \& Chang, H. F. (2011). A formative assessment-based mobile learning approach to improving the learning attitudes and achievements of students. Computers \& Education, 56(4), 1023-1031.

Hwang, G. J., Wu, P. H., \& Ke, H. R. (2011). An interactive concept map approach to supporting mobile learning activities for natural science courses. Computers \& Education, 57(4), 2272-2280.

Jacob, S., \& Issac, B. (2014). Mobile learning culture and effects in higher education. IEEE Education Society, 2(2), 19-21. Retrieved from http://arxiv.org/abs/1410.4379.

Jaradat, R. M. (2014). Students' attitudes and perceptions towards using m-learning for French language learning: A case study on Princess Nora University. International Journal of Learning Management Systems, 2(1), 33-44.

Karasar, N. (2012). Bilimsel arastırma yontemi: kavramlar, ilkeler, teknikler [Scientific Research Methods: Concepts, principles, techniques]. Ankara, Turkey, Nobel Publication Distribution.

Karsenti, T., \& Fievez, A. (2013). The iPad in education: Uses, benefits and challenges - A survey of 6,057 students and 302 teachers in Quebec, Canada. Montreal, QC: CRIFPE.

Keegan, D. (2005). The incorporation of mobile learning into mainstream education and training. World Conference on Mobile Learning, Cape Town (p.11), October. Retrieved from http: //www.mlearn.org/mlearn2005/CD/papers/keegan1.pdf.

Khaddage, F., \& Knezek, G. (2013). iLearn via mobile technology: A comparison of mobile learning attitudes among university students in two nations. In proceedings of 2013 IEEE 13th International Conference on Advanced Learning Technologies (ICALT), (Pp. 256-258). IEEE.

Kinash, S., Brand, J., \& Mathew, T. (2012). Challenging mobile learning discourse through research: Student perceptions of Blackboard Mobile Learn and iPads. Australasian Journal of Educational Technology, 28, 639-655.

Kukul, V., Gokcearslan S., \&Karademir, T. (2015). Pre-service Teacher's Attitude on Mobile Learning. In proceedings of Teaching and Education Conference, Amsterdam. International Institute of Social and Economic Sciences (pp. 119-127) (No. 2404091).

Kukulska-Hulme, A. (2007). Mobile usability in educational contexts: what have we learnt? The International Review of Research in Open and Distributed Learning, 8(2), 1-16.

Kutluk, F. A., \& Gulmez, M. (2014). A research about mobile learning perspectives of university students who have accounting lessons. Procedia-Social and Behavioral Sciences, 116, 291-297. 
Leech, N.L. Barlett, K.C. \& Morgan, G.A. (2005). SPSS for intermediate statistics; use and interpretation. Mahwah, NJ: Lawrence Erlbaum Associates.

Liaw, S., \& Huang, H. (2015). How factors of personal attitudes and learning environments affect gender difference toward mobile learning acceptance. The International Review of Research in Open and Distributed Learning, 16(4), 104132. Retrieved from http://www.irrodl.org/index.php/irrodl/article/view/2355.

MacCallum, K. S., \& Kinshuk, A. (2008). Mobile Discussion Boards: An Analysis on Mobile Collaboration. International Journal of Interactive Mobile Technologies, 2(1), 59.

Mertler, C. A., \& Vanatta, R. A. (2005). Advanced and multivariate statistical methods (3rd Ed.). Glendale, CA: Pyrzcak Publishing.

Milosevic, I., Zivkovic, D., Manasijevic, D., \& Nikolic, D. (2015). The effects of the intended behavior of students in the use of M-learning. Computers in Human Behavior, 51, 207-215.

O'Malley, C., Vavoula, G., Glew, J. P., Taylor, J., Sharples, M., \& Lefrere, P. (2003). MOBIlearn WP4 - Guidelines for learning/teaching/tutoring in a mobile environment. Retrieved from http://www.mobilearn.org/download/results/guidelines.pdf.

Ozdamli, F., \& Cavus N. (2011). Basic elements and characteristics of mobile learning. Social and Behavioral Sciences, 28, 937-942.

Ozdamli F., Soykan, E., \& Yildiz, E. P. (2013). Are Computer Education Teacher Candidates Ready for M-Learning? Procedia - Social and Behavioral Sciences, 83, 1010-1015. doi:10.1016/j.sbspro.2013.06.188.

Ozdamli, F., \& Uzunboylu, H. (2015). M-learning adequacy and perceptions of students and teachers in secondary schools. British Journal of Educational Technology, 46(1), 159-172.

Pallant, J. (2005). SPSS Survival Manual: A step by step guide to data analysis using spss for windows. Australia: Australian Copyright.

Park, Y. (2011). A pedagogical framework for mobile learning: Categorizing educational applications of mobile technologies into four types. The International Review of Research in Open and Distributed Learning, 12(2), 78-102.

Pfeiffer, V. D., Gemballa, S., Jarodzka, H., Scheiter, K., \& Gerjets, P. (2009). Situated Learning in the Mobile Age: Mobile Devices on a Field Trip to the Sea.ALT-J: Research in Learning Technology, 17(3), 187-199.

Quinn, C. (2000). mLearning: Mobile, wireless, in-your-pocket learning. LiNE Zine, Fall 2000.Retrieved fromhttp://www.linezine.com/2.1/features/cqmmwiyp.htm.

Rossing, J. P, Miller, W. M., Cecil, A. K., \& Stamper, S. E. (2012). iLearning: The Future of Higher Education? Student Perceptions on Learning... Journal of Scholarship of Teaching and Learning, 12(2), 1-26.

Sarac, A. (2014). Yeni bir egitim platformu olarak mobil ogrenme ortamları icin uygulama gelistirmenin onemi ve ogretim teknologu adaylarının algıları uzerine bir arastırma [The Importance Of Application Development For The Mobile Learning Environments As A New Education Platform And A Research On Instructional Technologist Candidates's Perceptions](Master's Thesis, Marmara University, Istanbul, Turkey). Retrieved from https://tez.yok.gov.tr/UlusalTezMerkezi/367843.

Sarrab, M. (2015). Mobile Learning (m-learning) Concepts, Characteristics, Methods, Components: Platforms and Frameworks. New York: Nova Science Publishers.

Schwabe, G., \& Goth, C. (2005). Mobile learning with a mobile game: design and motivational effects. Journal of computer assisted learning, 21(3), 204-216. 
Sharples, M. (2000). The design of personal mobile technologies for lifelong learning. Computers \& Education, 34(3), 177-193.

Shon, J. G. (2008). M-Learning Trends in Korea. Presentation at the ISO/IEC JTEC1/SC36 Open Forum, Seoul, Korea, March 2008.

Suki, N. M., \& Suki, N. M. (2011a).Using Mobile Device for Learning: From Students' Perspective. US-China Education Review, A1 (1), 44-53.

Suki, N. M., \& Suki, N. M. (2011b). Users' Behavior towards Ubiquitous M-Learning. Turkish Online Journal of Distance Education, 12(3), 118-129.

Sung, E., \& Mayer, R. E. (2013). Online multimedia learning with mobile devices and desktop computers: An experimental test of Clark's methods-not-media hypothesis. Computers in Human Behavior, 29(3), 639-647.

Tabachnick, B.G. \& Fidell, L.S. (2007). Using Multivariate Statistics. Boston, Pearson Education, Inc.

Taleb, Z., \& Sohrabi A. (2012). Learning on the move: the use of mobile technology to support learning for university students. Procedia - Social and Behavioral Sciences, 69, 1102-1109.

Tan, T-H., \& Liu, T-Y. (2004). The Mobile-based interactive learning environment (MOBILE)and a case study for assisting elementary school English learning. In IEEE International Conference on Advanced Learning Technologies, 2004. Proceedings. (pp. 530-534). IEEE. doi:10.1109/ICALT.2004.1357471

Toteja, R., \& Kumar, S. (2012). Usefulness of M-devices in education: A survey, Procedia Social and Behavioral Sciences, 67, 538-544.

Uzunboylu, H., Cavus, N., \& Ercag, E. (2009). Using mobile learning to increase environmental awareness. Computers \& Education, 52(2), 381-389.

Wang, Y.S., Wu, M.C., \&Wang, H.Y. (2009). Investigating the determinants and age and gender differences in the acceptance of mobile learning. British Journal of Educational Technology, 40(1), 92-118.

Wu, P. H., Hwang, G. J., Su, L. H., \& Huang, Y. M. (2012). A Context-Aware Mobile Learning System for Supporting Cognitive Apprenticeships in Nursing Skills Training. Educational Technology \& Society, 15(1), 223-236.

Yang S. (2012). Exploring college students' attitudes and self-efficacy of mobile learning. The Turkish Online Journal of Educational Technology, 11(4), 148-154.

Yilmaz, Y. (2011). Mobil ogrenmeye yonelik lisansustu ogrencilerinin ve ogretim elemanlarının farkındalık duzeylerinin arastırı/ması [Investigating the Awareness Levels of Postgraduate Students and Academics towards Mobile Learning] (Master's thesis, Dokuz Eylul University, İzmir, Turkey).Retrieved from http: / / acikerisim.deu.edu.tr/xmlui/ handle/12345/7189

Zaldivar, A., Tripp, C., Aguilar, J. A., Tovar, J. E., \& Anguiano, C. E. (2015). Using Mobile Technologies to Support Learning in Computer Science Students. Latin America Transactions, IEEE (Revista IEEE America Latina), 13(1), 377-382. 